\title{
The effect of a subject-specific AFO on the muscle activation during gait of a test subject suffering from a hemiparetic anterior muscle insufficiency in the lower leg
}

\author{
V Creylman ${ }^{1,2^{*}}$, L Muraru $^{1,2}$, H Vertommen ${ }^{1,2}$, L Peeraer ${ }^{1,3}$ \\ From 3rd Congress of the International Foot and Ankle Biomechanics Community \\ Sydney, Australia. 11-13 April 2012
}

\section{Background}

An Ankle Foot Orthosis (AFO) is commonly used in clinical practice to assist gait of patients with different pathologies. The flexibility of the AFO depends on different design characteristics while specific mechanical requirements of the AFO are correlated with patient anatomy and pathology. To this day, the correlation between AFO-design and patient pathology is mainly based on the orthopaedic technician's experience.

The aim of this study is to investigate the influence of the stiffness of an AFO on the muscle-activation pattern of a subject suffering from an anterior muscle insufficiency of the lower leg using a personalized musculoskeletal model.

\section{Materials and methods}

Test subject was a 40-year old male suffering from a hemiparetic anterior muscle insufficiency of the lower leg. A musculoskeletal model of the lower limbs with 23 degrees of freedom and 92 muscles was scaled in OpenSim to match the test subject's anthropometric data [1]. Muscle-definitions were adapted to simulate the patients' pathology.

A subject specific AFO was constructed using the selective laser sintering technique [2]. The actual stiffness of the AFO was determined using finite element analysis [3] and was $258 \mathrm{Nm} / \mathrm{rad}$.

Marker trajectories of an AFO-gait were used to calculate kinematic parameters and muscle-activation during gait using the musculoskeletal model. The AFO was

\footnotetext{
* Correspondence: veerle.creylman@khk.be

${ }^{1}$ Mobilab, University College Kempen, Belgium

Full list of author information is available at the end of the article
}

simulated as an angle-dependent torque around the ankle with a neutral angle of $0^{\circ}$. The stiffness of the AFO was varied between 150 and $350 \mathrm{Nm} / \mathrm{rad}$ in steps of $25 \mathrm{Nm} / \mathrm{rad}$.

\section{Results}

Results showed alternating muscle-activation in the affected lower leg with increasing AFO-stiffness. No clear correlation could be found between AFO-stiffness and muscle-activation.

\section{Conclusion}

An optimal AFO-stiffness in terms of muscle-activation can be selected for the patient. It must be kept in mind that these results are based on a calculation with a neutral AFO ankle position of $0^{\circ}$, and changing this neutral angle, affects the results.

\section{Author details \\ ${ }^{1}$ Mobilab, University College Kempen, Belgium. ²Division of Biomechanics, KULeuven, Belgium. ${ }^{3}$ Faculty of Kinesiology and Rehabilitation Sciences, KULeuven, Belgium.}

Published: 10 April 2012

\section{References}

1. Delp SL, Anderson FC, Arnold AS, Loan P, Habib A, John CT, Guendelman E, Thelen DG: OpenSim: Open-Source Software to Create and Analyze Dynamic Simulations of Movement. IEEE Trans Biom Eng 2007, 54:1940-1950.

2. Pallari JHP, Dalgarno KW, Munguia J, Muraru L, Peeraer L, Telfer $S$, Woodburn J: Design and Additive Fabrication of Foot and Ankle-Foot Orthoses. Proceedings of the 21st Annual International Solid Freeform Fabrication Symposium - An Additive Manufacturing Conference, 9-11 August 2010, Austin, Texas, USA

3. Muraru L, Creylman V, Pallari J, Willemsen R, Vander Sloten J, Peeraer L: Evaluation of functional parameters of ankle foot orthoses for different 
materials and design characteristics. Proceedings of the 13th World

Congress of the International Society for Prosthetics and Orthotics, May 10-15

2010 .

doi:10.1186/1757-1146-5-S1-P6

Cite this article as: Creylman et al:: The effect of a subject-specific AFO on the muscle activation during gait of a test subject suffering from a hemiparetic anterior muscle insufficiency in the lower leg. Journal of Foot and Ankle Research 2012 5(Suppl 1):P6.

Submit your next manuscript to BioMed Central and take full advantage of:

- Convenient online submission

- Thorough peer review

- No space constraints or color figure charges

- Immediate publication on acceptance

- Inclusion in PubMed, CAS, Scopus and Google Scholar

- Research which is freely available for redistribution

Submit your manuscript at www.biomedcentral.com/submit
C Biomed Central 